\title{
Community-Based Interventions To Improving Elderly's Socioeconomic Well-Being
}

\author{
Silvi Nur Indah ${ }^{1}$, Datu Jatmiko ${ }^{2}$, Poerwanti Hadi Pratiwi ${ }^{3}$ \\ ${ }^{123}$ Department of Sociology Education Faculty of Social Science Yogyakarta State University, Indonesia \\ ${ }^{1}$ silvi.nur2016@student.uny.ac.id,2jatmikodatu@uny.ac.id, ${ }^{3}$ ph_pratiwi@uny.ac.id
}

\begin{abstract}
Abtract. This study is motivated by the large numbers of elderly people in Indonesia from years which obtained from BPS, SUSENAS, SUPAS and population census data, one of them is Special Region of Yogyakarta. The present study aims to describe how the activities exist in Bina Keluarga Lansia (BKL) Melati, the function of BKL Melati in improving elderly's welfare and the driving and inhibiting factors in improving socioeconomic well-being of the elderly. This study used qualitative research methods. The sampling uses a purposive sampling technique with 7 respondents consisting of BKL Melati leader, staffs of BKL Melati, and BKL Melati members. The validity of the data used by researcher is source triangulation. Data analysis techniques using interactive model by Miles and Huberman. The results of this study indicate that the activities in BKL have 7 tough elderly dimensions such as spritual dimension, intellectual, physical, emotional, social, vocational professional, and environmental dimensions. The role of BKL Melati is to persuade the elderly to take part in activities, review and visit elderly at their home if they sick, provide help and support to the elderly in form of activities that benefit health and well-being of the elderly in social and economic sectors, facilitate the activities of the elderly at BKL Melati, etc.The driving factors for elderly activities are from the society and government in the form of funds, facilities, other supports and own efforts from the society. The inhibiting factors is the busy activities of the elderly and the health of themselves whose started to get sick.
\end{abstract}

Keywords: BKL Melati, elderly, roles, driving and inhibiting factors

\section{Introduction}

Elderly is a process of change that is passed by all people when given longevity by the almighty. The process of occurrence is inevitable, except for those who are not given the opportunity to enjoy old age. According to Law No. 13 of 1998 concerning welfare, Elderly is someone who has reached the age of 60 (sixty) years and over. According to the 2015 National Economic Socioeconomic Survey (Susenas), the percentage of households that have elderly is $24.1 \%$ while the elderly who live alone by the remaining $12.6 \%$ are living with other households. In 2019 the elderly in Indonesia are projected to increase to 27.5 million or $10.3 \%$ and 57.0 million or $17.9 \%$ in 2045 BPS, Bappenas, UNFPA, 2018.[1] There are 8.97\% (23.4 million) of elderly people in Indonesia, consisting of $8,48 \%$ of elderly men, and $9.47 \%$ of elderly women. There are more elderly women presentations than men BPS, 2017[2]. Based on the results of the 2015 Intercensal Population Survey (SUPAS), provinces in Indonesia 
which had the highest percentage of elderly population were Yogyakarta Special Region $13.6 \%$, Central Java 11.5\%, and Bali 10.4\% (BPS, 2016). In 2017 there were five provinces that had an old population structure in which the population had reached $10 \%$, namely; Special Region of Yogyakarta (13.90\%), Central Java (12.46\%), East Java (12.16\%), Bali (10.79\%), and West Sulawesi (10.37\%) BPS, 2017.[2]

Based on data obtained that the Special Region of Yogyakarta is the region that has the highest number of elderly population in Indonesia, the government recorded the results of the population census in the elderly in Yogyakarta in 2010 reaching $12.96 \%$ higher than the national percentage rate which was only $7.95 \%$ in in 2010. Life expectancy reaches 73.4 years, while national life expectancy is 70.7 years BPS, 2010.[3] Then in 2011 to 2018 life expectancy in Yogyakarta was as follows, in 2011 (74.26 years), 2012 (74, 36 years), 2013 (74.45 years), 2014 ( 74.50 years), 2015 ( 74.68 years), 2016 ( 74.71 years), 2017 (74.74 years), 2018 (74.82 years). One area that has a high rate of elderly in Yogyakarta is Sleman. The number of elderly people reaches 165,000 , which is $15 \%$ of the total population in Sleman which reaches 1.1 million people. According to the Deputy Regent of Sleman, Sri Muslimatun, the age range of the elderly in Sleman is 76 years. As the people getting older, the physical, psychological, social and economic conditions for the elderly become a measure of welfare for the elderly. Because the elderly are very vulnerable to physical conditions that are weak, and helpless. The problem of the elderly is not only becoming older, but at the same time are financially getting poorer, feeling lonely, and in need of more attention to the environment both family and social, wich is why they need welfare in the social and economic fields.

The action that the goverment take to provide services to the elderly in Yogyakarta, especially Sleman, is by facilitating the Happy Homes for the Elderly, the Elderly Family Development, and posyandu for the elderly by providing health checks on the elderly, empowering the elderly, or providing training for skills and being more productive in old age. BKKBN through the directorate of Elderly and Vulnerable Family Resilience Development also fosters and empowers Elderly Family Development (BKL) activity groups in all villages in Indonesia. Bangunkerto Village, Turi District, Sleman Regency, DIY, namely in Melati BKL. This research aims to study the activities, the role of BKL, inhibiting and driving factors in improving the socio-economic well-being of the elderly. BKL Melati is a mature consideration to be used as a place of research because it sees from the potential of the elderly who are active in productive, positive and beneficial activities, starting from the achievements of the last Elderly Family Development is the 1st National Champion in 2018. Elderly Family Development (BKL) Melati as the Center of Excellent (CoE), which means to be a reference for assistance programs for elderly citizens.

BKL Melati applies 7 dimensions of resilient elderly in improving the socio-economic well-being of the elderly consisting of elderly activities. Elderly needs consist of physical, psychological, social needs, knowledge and skills, economic needs, and spiritual needs Khotimah, N., et al, 2018.[4] In improving the socio-economic well-being of the elderly, it needs family support, the role of the family greatly affects the health of the elderly, if the role of the family is good then the health of the elderly will also be good, but conversely if the role of the family does not support then the health of the elderly will also be poor. The theory used in this study is the theory of activity, according to Neugarten and his friends, elderly people must remain as active as possible, that the older a person will increasingly maintain social, 
physical, and emotional relationships. The more elderly people are active and involved, the less likely they become old and the more likely they will be satisfied with their lives. The basic assumption of this theory is that the more active an elderly person is the more satisfied his/her life will be.

\section{Method}

This research is a qualitative research. This research was conducted in the city of Yogyakarta. The time of the study was conducted on December 23, 2019 to February 16, 2020. The research technique consisted of direct observation, interviews, documentation in the form of books, archives, documents, writing numbers and pictures containing reports. This research uses purposive sampling. Purposive sampling technique is a technique chosen by researchers where researchers choose varied based on reasons. The researcher has several criteria for informants, among others (1) The informant is an official manager of the Elderly Family Development, (2) Has arranged the elderly for a long time, (3) Knowing and mastering information about the elderly at BKL, (4) As an active participant who needs and helps service to the elderly. Data validity uses source triangulation. Data validity uses source triangulation. The analysis technique in this study was proposed by Miles and Huberman (2014) analyzing with 3 steps namely condensing data, presenting data, and drawing conclusions or verification.

\section{Result and Discussion}

Research results in the field is that activities in Melati BKL have 7 dimensions of resilient elderly, namely: (1) Spiritual Dimension that enhances the faith and piety of BKL Melati members through recitation, pangruptiloyo, mujadahan, hadroh, and yasinan activities. (2) Intellectual Dimension whose purpose is to make the elderly restore their memories, and the way of thinking of the elderly so as not to be senile and decrepit through single organ activities or singing, choirs, contests, musical instruments, simulation drawing exercises, coloring exercises, comparative studies, recreation, speech exercises, picture book questions and answers, and game simulations. (3) Physical dimensions whose purpose is to provide positive activities for the health of the elderly through the activities of elderly gymnastics, elderly Posyandu, and healthy walking. (4) Emotional dimension which aims to train and control patience and emotional well-being in the elderly through psychological service activities, and media play. (5) Social dimension which aims to strengthen friendship between citizens through social gathering activities, observations, visits, and visits from outside. (6) Vocational Professional Dimensions whose aim is to make the elderly more productive in their old age through productive economic activities, participating in cooking competitions, and training activities. (7) Environmental Dimensions whose purpose is to provide awareness of the hygiene of the surrounding environment through the activities of TAMBULAMPOT (Planting Fruit in Pot), cleaning up graves, and collecting plastic waste for processing.

The results of subsequent studies are the role of BKL in improving socio-economic welfare, namely (a) Providing direction to the elderly to participate in activities in the Melati 
Elderly Family Development (BKL), (b) Providing care and attention to the elderly through elderly visits, (c) Providing social services and coaching to the elderly at the Melati Elderly Family Development (BKL), (d) provide guidance to children of the elderly or to the young mothers who have elderly at home to motivate the elderly, through activities in BKL Melati, (e) Facilitating activities visits from outside and sharing knowledge related to activities in the BKL, (f) Providing skills in productive economic activities and facilitating productive economic training activities, (g) Providing assistance to the elderly to prosper, (h) Helping the elderly to maintain the ability to think and Give attention to the elderly in old age, (i) Provide the role of the Melati Elderly Family Development members (BKL) Melati and local government.

The other result of studies are inhibiting and driving factors for Melati BKL in increasing Socio-Economic Welfare. There are two driving factors namely internal and external. The driving factor (internal) is the elderly's good relationship between the each other, the elderly with the community, and the elderly with the government, the existence of family support in the implementation of activities in the Elderly Family Development (BKL) Melati. The benefits of the activities obtained in the activities of Family Development Elderly (BKL) Melati, the achievements obtained by the Elderly Family Development (BKL) Melati through competitions and the declaration of CEO (Center of Excelent). The Driving factors (External), namely adequate facilities provided by the government, participation from the government and the community in assisting funding for activities in the Elderly Family Development (BKL). Jasmine The government facilitates recreational activities by providing transportation in the form of buses, providing services for the elderly in improving elderly socio-economic welfare, social support from the community and government in the implementation of activities in the Melati Elderly Family Development (BKL). There are also 2 kinds of internal and external inhibiting factors. Internal inhibiting factors Lack of emotional control in the elderly. External inhibiting factors, lack of funding in activities can be a limiting factor, limited time for the elderly to carry out activities in BKL Melati due to busyness and sick elderly, there are problems in the living conditions of the elderly and elderly families in the productive economy.

\section{Conclusion}

Based on the results of the research above, BKL Melati is a place of guidance for the elderly, through its activities BKL Melati can improve the welfare of the elderly in the socioeconomic field. The results of research at BKL Melati consist of 7 dimensions of resilient elderly people, the activities carried out at BKL Melati. The seven dimensions of resilient elderly consist of spiritual, intellectual, emotional, physical, vocational, social, and environmental dimensions. Then get results in the form of the role of BKL Melati in improving socio-economic welfare including giving direction to the elderly to participate in activities in BKL Melati, providing care and attention, providing social services, and others. Furthermore, there are driving and inhibiting factors in improving the welfare of the elderly in the socio-economic field. 


\section{References}

[1] BPS. (2018). Angka Harapah Hidup Tahun 2011-2018. Yogyakarta. Tersedia di: (https://yogyakarta.bps.go.id/) diakses pada tanggal 8 November, pukul 15.01 WIB.

[2] BKKBN. (2019). Info Demografi. Tersedia di: (https://www.bkkbn.go.id/pocontent/uploads/info_demo_vol_1_2019_jadi.pdf) diakses pada tanggal 8 November 2019, pukul 13.23 WIB.

[3] BKKBN. (2010). Pedoman Pengelolaan BKL. Semarang: BKKBN

[4] Khotimah, N., Pratiwi, .PH., Fitriana, K.N. (2018). Pengembangan Model Pelayanan Kesejahteraan Sosial Bagi Lansia dalam Menghadapi Ageging Population di DIY. Laporan Penelitian.Yogyakarta: UNY dan Kemenristekdikti RI.

[5] BKKBN. (2011). Bina Keluarga Lansia (BKL). Yogyakarta: Perwakilan Badan Kependudukan dan Keluarga Berencana Nasional Provinsi DIY

[6] BKKBN. (2014). Bina Keluarga Lansia (BKL). Yogyakarta: BKKBN Provinsi Daerah Istimewa Yogyakarta.

[7] BKKBN. (2014). Lansia Tangguh Tujuh Dimensi. Jakarta: BKKBN.

[8] Fahrudin, Adi. (2012). Pengantar Kesejahteraan Sosial. Bandung: PT Riefka Aditama.

[9] Khotimah, dkk. (2019). Social Protection for Elderly in Emergency (Case Study: Yogyakarta Special Region, Indonesia). Earth and Environmental Science,271.

[10] Miles,M.B, Huberman,A.M, dan Saldana,J. (2014). Qualitative Data Analysis, A Methods Sourcebook, Edition 3. USA: Sage Publications. Terjemahan Tjetjep Rohindi Rohidi, UI-Press.

[11] Moleong, L.J. (2011). Metodologi Penelitian Kualitatif Edisi Revisi. Bandung: PT Remaja Rosdakarya.

[12] Prabasari, Juwita, Maryuti. (2017). Pengalaman Keluarga Dalam Merawat Lansia Di Rumah (Studi Fenomenologi). Jurnal Ners LENTERA, 5(1), 60-63. Retrieved from http://jurnal.wima.ac.id/index.php/NERS/article/view/1573/1462.

[13] Saputri, C. (2016). Bina Keluarga Lansia (BKL) Roles in Improving The Elderly Health Trough Taman Pendidikan Lansia (TPL) in Rw 11 Klitren Village Gondokusuman District Yogyakarta City. Journal Student UNY, 240-244.

[14] Sari, Melani Kartika. (2016). Peningkatan Kualitas Hidup Lansia Menggunakan Reminiscence Affirmative TherapyBerbasis Teori Lazarus. Jurnal Ners LENTERA, 4(1), 82-85. Retrieved fromhttp://jurnal.wima.ac.id/index.php/NERS/article/view/872/841

[15] Suadirman Siti Partini. (2011). Psikologi Usia Lanjut.Yogyakarta: Gajah Mada University Press. 